\title{
Towards characterization of Eurasian crop fruit resources: biochemical marker profiles in Azerbaijani and Iranian pomegranate cultivars under cold stress
}

\author{
Alessandra Podda \\ Paola Bartolini \\ CNR-IPSP - Department of Biological Sciences, Protection of \\ Plants, Research Area Florence, via Madonna del Piano 10, \\ Florence, Italy \\ Aydan M. Zeynalova \\ Institute of Botany, Azerbaijan National Academy of Sciences, \\ Badamdar 40, Baku, AZ1004, Azerbaijan \\ Ferdinando Cossio \\ International Fruit Consultant, Plant breeder, Roma, Italy \\ Ebrahim Latifikhah \\ Research Centre for Agriculture and Natural Resources, Kashan \\ Station, Kashan, I.R. Iran \\ Mirza K. Musayev \\ Genetic Resources Institute, Azerbaijan National Academy of \\ Sciences, Avenue 155, Azadlig, Baku, AZ1106, Azerbaijan \\ Biancaelena Maserti ${ }^{1}$ \\ CNR-IPSP - Department of Biological Sciences, Protection of \\ Plants, Research Area Florence, via Madonna del Piano 10, \\ Florence, Italy
}

Abstract: Nowadays, pomegranate (Punica granatum L.) cultivation increased in Mediterranean countries due to the fruit nutritional quality and the ability to withstand soil salinity. Thus, the knowledge of its response mechanisms to environmental stress gains importance. On the other hand, landraces, generally cultivated in harsh environments may represent a source of resistance genes useful for breeding new tolerant cultivars. In this work buds (five month-old) of eleven Azerbaijan, six Iranian pomegranate landraces as well as the buds of the cultivar Wonderful were exposed to $48 \mathrm{~h}$ mild cold stress $\left(-4^{\circ} \mathrm{C}\right)$. Oxidative stress parameters, such as lipid peroxidation, hydrogen peroxide, and proline as well as the superoxide dismutase activity were measured in control and stressful buds. Upon cold stress, lipid peroxidation, hydrogen peroxide levels and proline were higher in all the varieties than in the normal buds. However, the levels of the studied biomarkers were lower in the Iranian Saveh and the Azerbaijan Bala Mursal respect to the modern cultivar Wonderful. Higher levels of enzymatic activitiy of superoxide dismutase were detected in all cold stressed buds, especially in those from cultivar "Wonderful" respect to the normal ones. These results may suggest that the landraces Saveh and Bala Mursal were less affected by cold stress. On the other hand, the strong activation of antioxidant enzyme in Wonderful might be pivotal for its survival under stress. This work shows differences in oxidative stress parameters as well as superoxide dismutase activity among pomegranate cultivars upon cold stress.

Keywords: abiotic stress, antioxidant enzyme, landraces, plant stress, Punica granatum

\section{INTRODUCTION}

Selected resistant genes of crop species wild relatives and landraces growing in harsh environments can be the key to cope both biotic and abiotic changes [Miller et al., 1992].

Recently, in Mediterranean countries, climate variability with alternation of very warm days followed by fast temperature decrease at levels under the seasonal means is observed in spring [IPCC, 2014]. It could results in freezing of young buds and consequently loss or decrease of crop plant productivity.

Pomegranate originated in the Fertile Crescent and then spread to the East to Asia and China, in North America and in Europe [Da Silva et al., 2011]. In recent years, the cultivation and the consumption of pomegranate gains importance as its fruit has been defined as "super fruit" [Cassel, 2012] due to the high content of potent antioxidant compounds such flavonoids and polyphenols [Faria, Calhau, 2011; Johanningsmeier, Harris, 2011]. Hence, the high adaptability to different soil and most of all, the capacity to withstand salinity had supported the switch from citrus to pomegranate production in several Mediterranean countries [Finnegan, Gokcekus, 2015].

Despite the increased interest for pomegranate production, the information of the response mechanisms to environmental stress in this plant are very few. M.R. Naeinia et al. [2015] studied the effects of salinity on the nutritional content of three commercial pomegranate varieties. P. Bhantana and N. Lazarovitch [2010] studied the evapotranspiration, crop coefficient

1E-mail: elena.maserti@ipsp.cnr.it

Received 22.10.2021; Received in revised form 03.11.2021; Accepted 15.11.2021 
and growth in pomegranate under salt stress. S. Catola et al. [2016] reported enhanced levels of biochemical parameters and green leaf volatiles in pomegranate under drought stress. A.A.G. Soloklui and A. Ershadi [2012] evaluated the cold stress effects in several Iranian landraces. After measuring the electrolytic leakage and carbohydrate content, the authors observed different resistance to cold hardiness among the studied pomegranate varieties. However, by our knowledge, no information are available on the biochemical response to cold in pomegranate plants.

Thus, in the framework of an international project the response mechanisms to environmental stress in less exploited crop landraces of Eurasian and Middle Asia countries is characterised. We studied the effects of cold stress in the young buds of eleven Azerbaijan, six Iranian landraces as well as of the modern "Wonderful" pomegranate cultivar and evaluated the induced oxidative stress in terms of membrane lipid peroxidation, hydrogen peroxide and proline content. Additionally the antioxidant response of the plants was measured assessing the activity of superoxide dismutase (SOD) by in-gel activity staining.

\section{MATERIAL AND METHODS}

Plant Material. The Azerbaijan and Iranian landraces as well as the "Wonderful", one of the most cultivated cultivar in Europe, were grown in field conditions at Maule Exotic Plants Nursery (Cisterna di Latina, LT, Italy) for three years (Tab.).

Cold stress treatment. Twigs of about five months of age, bearing 2-3 buds, each containing 5 young leaves, were harvested from two plants of each pomegranate variety on April 12, 2016. After harvesting, the end of the twigs were sealed with parafilm (American National Can, Menasha, WI), and each twig was wrapped in a wet paper towel to avoid desiccation upon delivering to the laboratory. For cold treatment, each twig bottom was put into an $1.5 \mathrm{~mL}$ Eppendorf tube filled with distilled water and sealed with Parafilm to avoid evaporation. Then twigs were kept at $-4^{\circ} \mathrm{C}$ for $18 \mathrm{~h}$ in a dark to simulate a winter night. As a control, twigs were kept at $25^{\circ} \mathrm{C}$ in a growth chamber in a dark. Three biological replicates were used for biochemical analysis.

Lipid peroxidation. Lipid peroxidation was measured as malondialdehyde (MDA) content $\left(\varepsilon=155 \mathrm{mM}^{-1} \mathrm{~cm}^{-1}\right)$, following the method of R.L. Heath and L. Packer [1968] with some modifications reported in Catola et al. [2016]. The MDA content was determined using a standard curve and expressed as nmol $\mathrm{MDA} \mathrm{g}^{-1} \mathrm{FW}$.

Hydrogen peroxide content. The hydrogen peroxide $\left(\mathrm{H}_{2} \mathrm{O}_{2}\right)$ levels in the buds were determined according to the procedure described by S. Junglee et al. [2014] and calculated against a standard curve. The content was expressed as $\mu \mathrm{mol} \mathrm{H}_{2} \mathrm{O}_{2} \mathrm{~g}^{-1} \mathrm{FW}$.

Proline content. The extraction and determination of proline in the young buds of pomegranate were performed modifying the method of L.E. Bates [1973], as described in S. Catola et al. [2016]. The content was calculated against a standard curve and expressed as $\mu \mathrm{mol}$ proline $\mathrm{g}^{-1} \mathrm{FW}$.

Superoxide in-gel activity (SOD) assay. For the determination of SOD activity, $100 \mathrm{mg}$ of young leaves were homogenized in $200 \mu \mathrm{l}$ [cold $50 \mathrm{mM} \mathrm{K-phosphate}$ buffer ( $\mathrm{pH}$ 7.8), $1 \mathrm{mM}$ ethylenediamine tetraacetic acid (EDTA), 1\% (w/v) polyvinyl-pyrrolidone (PVP) and $0.1 \%(\mathrm{v} / \mathrm{v})$ Triton X-100, buffer with mortar and pestle. The slurry was centrifuged at $4^{\circ} \mathrm{C}$ for $15 \mathrm{~min}$ at $15000 \mathrm{~g}$. Protein concentration in the extract was determined according to M.M. Bradford [1976] using bovine serum albumine to generate a standard curve. After protein assay, samples were stored at $-20^{\circ} \mathrm{C}$ until use.

Table. Pomegranate varieties used.

\begin{tabular}{cccc}
\hline \hline Pomegranate variety & Region & Pomegranate variety & Region \\
\hline Azeri & Azerbaijan & Wonderful & Europe-USA \\
Qirmizi Guleysha & Azerbaijan & Iran 1 & Iran \\
Farash & Azerbaijan & Iran 2 & Iran \\
Respublika & Azerbaijan & Iran Black & Iran \\
Veles & Azerbaijan & Saveh & Iran \\
Qirmizi veles & Azerbaijan & Al Siri Nar & Iran \\
Seferzi & Azerbaijan & Pust Ghermez Saveh & Iran \\
Guleysha & Azerbaijan & & \\
Bala Mursal & Azerbaijan & & \\
Qirmizi qabuq & Azerbaijan & & \\
Qashang & Azerbaijan & & \\
\hline
\end{tabular}


Native polyacrylamide gel electrophoresis (PAGE) was performed at $4{ }^{\circ} \mathrm{C}$ in $10 \%$ polyacrylamide gel with $10 \%$ glycerol (w/v). The same amount of protein was loaded in each gel lane. SOD activity staining was carried out according to S. Beauchamp and I. Fridovich [1971] with minor modifications. SOD activity in gel was evaluated by using Image Lab software version 5.2.1 (BioRad), by comparing the activity of each SOD enzyme, the intensity value of $200 \mathrm{ng}$ of Mn-SOD from Escherichia coli (Sigma Aldrich S5639) loaded in the first lane of the gel.

Statistical analysis. Biochemical analysis are means of three biological replicates for each experimental condition (control and cold stressed leaves). One-way ANOVA with the Tukey post hoc test was used to find significant differences at $\mathrm{P}<0.05$, using Statistica 10.0 (StatSoft software, Inc., USA).

\section{RESULTS AND DISCUSSION}

Cold stress results in destroying of polyunsaturated fatty acids (PUFA) and consequently changes in membrane physical and chemical properties of the exposed plants [Miura, Furumoto, 2013]. Malondialdehyde (MDA) being a by-product of PUFA is considered a biomarker of lipid peroxidation and membrane deterioration [Malenčić et al., 2004; Ayala et al., 2014]. Thus, in this work the MDA content was used to determine the effect of cold on cell membrane. The buds from all the 18 pomegranate cultivars had a significant higher MDA levels under low temperature compared to the control ones, however the "Wonderful" showed the highest value $\left(0.82 \mu \mathrm{mol} \mathrm{g}^{-1} \mathrm{FW}\right)$. On the other hand, the MDA content in cold stressed buds of "Saveh" and "Bala Mursal" was lower (around $0.23 \mu \mathrm{mol} \mathrm{g}^{-1} \mathrm{FW}$ ) than in the other stressed cultivars (Fig. 1) and this finding

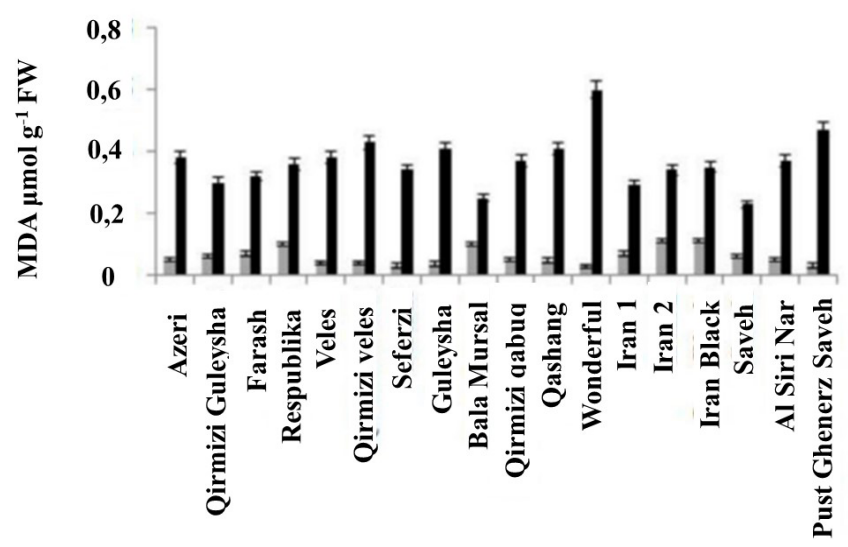

Figure 1. Levels of lipid peroxidation measured as MDA content in the buds of control (grey), cold-stressed (black) pomegranate cultivars. might be correlated to reduced lipid peroxidation.

A.A.G. Soloklui and A. Ershadi [2012] found less electrolyte leakage in the cultivar "Saveh" exposed to cold stress, suggesting the maintenance of cell membrane integrity which is an important traits for plants resistance to hypothermia [Takahashi et al., 2013].

As expected, upon cold-stressed, the $\mathrm{H}_{2} \mathrm{O}_{2}$ content increased from around $5 \mu \mathrm{mol} \mathrm{g}^{-1}$ measured in control buds to $15 \pm 0.8 \mu \mathrm{mol} \mathrm{g}{ }^{-1}$, FW which was the highest value and was observed in the "Wonderful" cultivar. Interesting cold-stressed buds of "Saveh" and "Bala Mursal" showed the lowest values around $8.1 \pm 0.3$ $\mu \mathrm{mol} \mathrm{g}{ }^{-1}, \mathrm{FW}$ and $8.9 \pm 0.2 \mu \mathrm{mol} \mathrm{g}^{-1}, \mathrm{FW}$, respectively

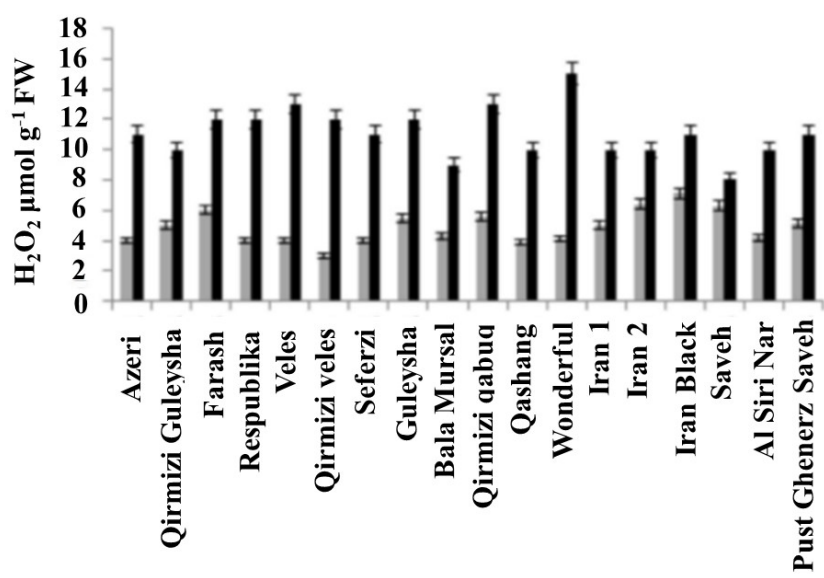

Figure 2. Levels of $\mathrm{H} 2 \mathrm{O} 2$ in the buds of control (grey), cold-stressed (black) pomegranate cultivars.

(Fig. 2).

Plants produce reactive oxygen species (ROS) such as $\mathrm{H}_{2} \mathrm{O}_{2}$ under normal conditions and there is a fine balance between production and scavenging to maintain a steady-state level. Cold hardiness enhances ROS production due to stomatal closure and the concomitant limitation on $\mathrm{CO}_{2}$ fixation [Miura, Furumoto, 2013]. The oxidative burst lead to disturbance of the cellular redox balance and is toxic to cells. On the other hand, the overproduction of $\mathrm{H}_{2} \mathrm{O}_{2}$ can act as signalling molecule triggering accumulation of cellular protectants that may act in the regulation of the cellular redox-status. In this regards, the increased amount of the osmoprotectant proline in all cold-stressed buds may confirm this hypothesis (Fig. 3) and is in accordance with the observation of A.A.G. Soloklui and A. Ershadi [2012] in Iranian landraces under cold hardiness.

SOD is the first line of defence against injury caused by ROS, by catalyzing the dismutation of $\mathrm{O}_{2}$ into $\mathrm{H}_{2} \mathrm{O}_{2}$ 
and molecular oxygen. In this research to evaluate, the in-gel activity procedure was used as this technique changes in SOD activity to detect the activity of single SOD isoenzyme on polyacrylamide gels. After the native polyacrylamide gel electrophoresis separation, the activity of one SOD isozyme were found more abundant in several cultivars upon cold stress (Fig. 4 a, b) especially in "Wonderful".

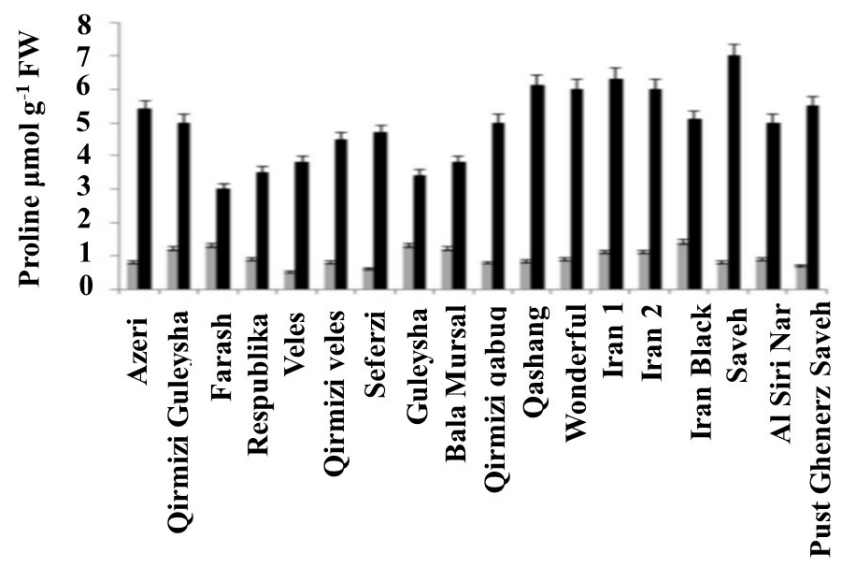

Figure 3. Levels of proline in the in the buds of control (grey), cold-stressed (black) pomegranate cultivars.

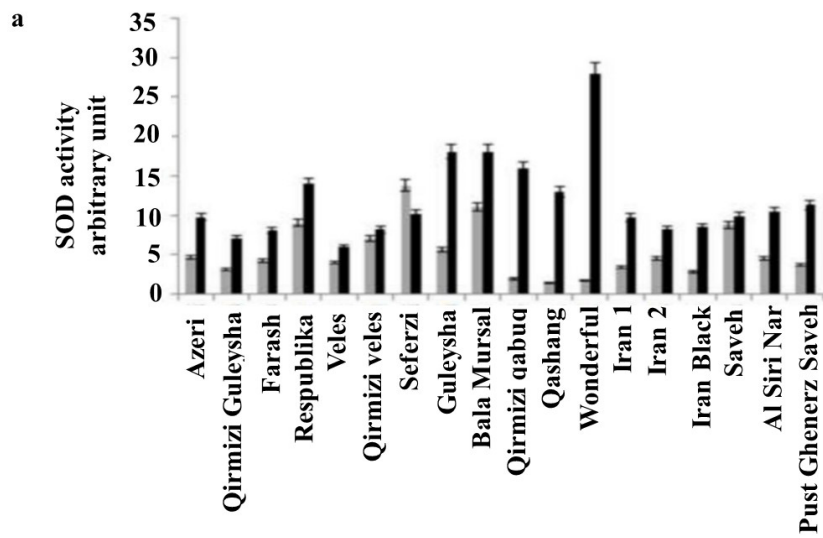

b

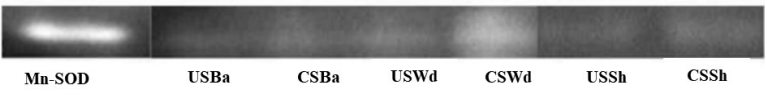

Figure 4. Relatives intensities of superoxide dismutase activity (arbitrary units) in control (grey) and cold-stressed (black) buds of pomegranate (a). The activity value of each cultivar was normalized against the activity value of $200 \mathrm{ng}$ of Mn-SOD loaded on the same gel. Light bands show the in-gel activity of superoxide dismutase measured in standard enzyme (Mn-SOD); control buds (USBa), cold-stressed (CSBa) Bala, control (USWd), cold-stressed (CSWd); control (USSh) cold - stressed (CSSh) Saveh cultivars and standard SOD (SOD) (b).

\section{CONCLUSION}

Data reported in this work show that the two pomegranate landraces, namely the Azerbaijan Bala Mursal and the Iranian Saveh seem less affected to fast cold stress respect to the modern variety Wonderful. The cold-triggered modulation of biochemical markers observed in the Iranian Saveh may be due to genetic or epigenetic modifications as the area from which Saveh originated, is affected by hot summer and harsh winter with fast decrease of temperature. However, further investigations should be performed to elucidate the potential resistance mechanisms.

In conclusion, this work underlines the importance of studying the stress response mechanism of less exploited genetic resources of landraces both for preserving biodiversity, and as potential sources of resistance genes useful for breeding more resistant varieties.

\section{ACKNOWLEDGEMENTS}

The authors thank Mr Francesco Maule, owner of Exotic Plant Vivaio (Latina, Italy) for kindly providing the pomegranate buds used in this work. The work was supported by a grant to Dr. Biancaelena Maserti for the bilateral project MOXIVOL between National Research Council, Italy and Azerbaijan National Academy of Science, Azerbaijan.

\section{REFERENCES}

Ayala A., Muñoz M.F., Argüelle S. (2014) Lipid peroxidation: production, metabolism, and signaling mechanisms of malondialdehyde and 4-hydroxy-2nonenal. Oxidative Medicine and Cellular Longevity, $1-31$.

Bates L.E., Walden R.P., Teare I.D. (1973) Rapid determination of free proline for water stress studies. Plant Soil, 39: 205-207.

Bhantana P., Lazarovitch N. (2010) Evapotranspiration, crop coefficient and growth of two young pomegranate (Punica granatum L.) varieties under salt stress. Agr. Water Manage., 97: 715-722.

Beauchamp C., Fridovich I. (1971) Superoxide dismutase: improved assays and an assay applicable to acrylamide gels. Anal. Biochem., 44(1): 276-87.

Bradford, M.M. (1976) A rapid and sensitive method for the quantitation of microgram quantities of protein utilizing the principle of protein-dye binding. Annals. Biochem., 72: 248-254.

Cassell D. (2012) Pomegranate retains superfruit status. Food Processing Magazine. http://www. 
foodprocessing.com/articles/2012/pomegranateretains-superfruit-status/

Catola S., Emiliani G., Marino G., Huseynova T., Musayev M., Akparov Z., Maserti B.E. (2016) Physiological and metabolomic analysis of Punica granatum ( L. ) under drought stress. Planta, 243: 441-449.

Da Silva J.A.T., Rana T.S., Narzary D., Verma N., Meshram D.T., Ranade S.A. (2013) Pomegranate biology and biotechnology: a review. Sci. Hortic., 160: $85-10$.

EDGE(2008) Unlocing the Tur ish Cypriot Community's potential by providing keys toeconomic growth. http://pdf.usaid.gov/pdf_docs/pdacx162.pdf

Faria A., Calhau C. (2011) The bioactivity of pomegranate: impact on health and disease. Cri. Rev. Food Sci. Nutr., 51:626-634.

Finnegan C.M., Gokcekus O., (2015) Developing countries: a case study of the Tur ish Cypriot Community's adoption of pomegranate farming. In the sustainability of AgroFood and Natural Resource Systems in the Mediterranean Basin. A Vastola Ed. Springer Open. pp159-171. DOI 10.1007/978-3319-16357-4 11

Gill S.S., Tuteja N. (2010) Reactive oxygen species and antioxidant machinery in abiotic stress tolerance in crop plants. Plant Physiol. Biochem., 48: 909-30.

Gupta S., Heinen J.L., Holaday A.S., Burke J.J., Allen R.D. (1993) Increased resistance to oxidative stress in transgenic plants that overexpress chloroplastic $\mathrm{Cu} / \mathrm{Zn}$ superoxide dismutase. P. Natl. Acad. Sci., 90: 1629-1633.

Heath R.L., Packer L. (1968) Photoperoxidation in isolated chloroplast. I. Kinetics and stoichiometry of fatty acid peroxidation. Arch Biochem Biophys 125: 189-198

Johanningsmeier S.D., Harris G.K. (2011) Pomegranate as a functional food and nutraceutical source. Annu. Rev. Food Sci. Technol., 2: 181-201.

Junglee S., Urban L., Sallanon H., Lopez-Lauri F., (2014) Optimized assay for hydrogen peroxide determination in plant tissue using potassium iodide. Am. J. Anal. Chem., 5: 730-736.

Malenčić Dj., Vasić D., Popović M., Dević D. (2004) Antioxidant systems in sunflower as affected by oxalic acid. Biol. Plantarum, 48: 243-247.

Mishra S., Jha A.B., Dubey R.S. (2011) Arsenite treatment induces oxidative stress, upregulates antioxidant system and causes phytochelatin synthesis in rice seedlings. Protoplasma, 248: 565-
577.

Miura K., Furumoto T. (2013) Cold signaling and cold response in plants. Int. J. Mol. Sci. 14: 5312-5337.

Naeinia M.R., Khoshgoftarmanesh A.H., Lessanic H., Fallahid E. (2005) Effects of sodium chlorideinduced salinity on mineral nutrients and soluble sugars in three commercial cultivars of pomegranate. J. Plant. Nutr., 27: 1319-1326.

Sharma P., Dubey R.S. (2005) Drought induces oxidative stress and enhances the activities of antioxidant enzymes in growing rice seedlings. Plant Growth Regul., 46: 209-221.

Soloklui A.A.G., Ershadi A. (2012) Evaluation of cold hardiness in seven Iranian commercial pomegranate (Punica granatum L.) cultivars. Hortscience, 47(12): 1821-1825.

Takahashi D., Li B. Nakayama T., Kawamura Y., Uemura M. (2013) Plant plasma membrane proteomics for improving cold tolerance. Front. Plant Sci., 4: 90.

Xu J., Yang J., Duan X., Jiang Y., Zhang P. (2014) Increased expression of native cytosolic $\mathrm{Cu} / \mathrm{Zn}$ superoxide dismutase and ascorbate peroxidase improves tolerance to oxidative and chilling stresses in cassava (Manihot esculenta Crantz). BMC Plant Biol., 14: 208 p.

\section{Avrasiya meyvə məhsulları ehtiyatlarının səciyyələndirilməsinə doğru: soyuq stress şəraitində Azərbaycan və İran nar sortlarının biokimyəvi marker profilləri}

\section{Alessandra Podda \\ Paola Bartolini \\ CNR-IPSP - Bioaqri va arzaq elmlori departamenti, Bitkilarin Davaml Mühafizasi Institutu, Florensiya, via Madonna del Piano 10, Florensiya, Italiva}

\section{Aydan M. Zeynalova}

AMEA Botanika İnstitutu, Badamdar şossesi 40, Bakı, AZ1004, Azərbaycan Ferdinando Kossio

Beynalxalq Meyva Masləhətçisi, seleksioner, Roma, İtaliya

Ebrahim Latifixah

Kand Tasarrüfatı va Tabii Sərvatlar Tadqiqat Markəzi, Kaşan stansiyası, Kaşan, İan İ.R.

\section{Mirzo K. Musayev}

AMEA Genetik Ehtiyatlar Institutu, Azadlıq prospekti 155, AZ1106, Bakl, Azarbaycan

\section{Biankaelena Maserti}

CNR-IPSP - Bioaqri va arzaq elmlori departamenti, Bitkilarin Davaml Mühafizasi Institutu, Florensiya, via Madonna del Piano 10, Florensiya, Italiya

Hazırda Aralıq dənizi ölkələrində qida keyfiyyətlərinə və torpağın şoranlaşmasına davamlılıq qabiliyyətinə 
görə narın (Punica granatum L.) becərilməsi artmışdır. Beləliklə, onun ekoloji stresə reaksiya mexanizmlərinə dair biliklər əhəmiyyət kəsb edir. Digər tərəfdən, adətən sərt şəraitdə yetişdirilən yerli sortlar yeni davamlı sortların yaradılması üçün faydalı olan davamlılıq genlərinin mənbəyi ola bilər. $\mathrm{Bu}$ tədqiqatda Azərbaycandan 11, İrandan 6 nar sortunun beş aylıq qönçələri, həmçinin "Wonderful" sortunun qönçələri 48 saatlıq yüngül soyuq stress şəraitində $\left(-4^{\circ} \mathrm{C}\right)$ saxlanılmışdır. Lipid peroksidləşməsi, hidrogen peroksid və prolin kimi oksidləşdirici stress parametrləri, həmçinin superoksid dismutazanın aktivliyi kontrol və stresə məruz qalan tumurcuqlarda ölçülmüşdür. Soyuq stresi altında lipidlərin peroksidləşməsi, hidrogen peroksid və prolinin səviyyələri bütün sortlarda normal tumurcuqlara nisbətən daha yüksək olmuşdur. Bununla belə, tədqiq edilən biomarkerlərin səviyyələri "Wonderful" ilə müqayisədə İran sortu "Saveh" və "Bala Mürsəl" Azərbaycan sortunda daha aşağ1 olmuşdur. Superoksid dismutazanın fermentativ aktivliyinin soyuq stresə məruz qalan bütün tumurcuqlarda, xüsusən də "Wonderful" sortunun tumurcuqlarında normal qönçələrlə müqayisədə daha yüksək səviyyəsi aşkar edilmişdir. Bu nəticələr "Saveh" və "Bala Mürsəl" sortlarının soyuq stresindən daha az zərərçəkdiyini göstərir. Digər tərəfdən, "Wonderful" sortunda antioksidant fermentin güclü fəallığı onun stresə davamlılığ1 üçün vacib ola bilər. Bu tədqiqat soyuq stresi şəraitində nar sortları arasında oksidləşdirici stresin parametrlərində, həmçinin superoksid dismutazanın aktivliyindəki fərqləri göstərir.

Açar sözlar: abiotik stress, antioksidant ferment, yerli sort, bitki stresi, Punica granatum

\section{К характеристике плодовых ресурсов евразийских культур: профили биохимических маркеров азербайджанских и иранских сортов граната в условиях холодового стресса}

\section{Алессандра Подда \\ Паола Бартолин \\ CNR-IPSP - Отдел биологических и пищевых наук, Институт по устойчивой защчите растений, Флоренция, via Madonna del Piano 10, Флоренция, Италия}

Айдан М. Зейналова

Институт Ботаники НАН Азербайджсана, Бадамдарское шоссе 40, Баку, AZ1004, Азербайджан

Фердинандо Коссио

Международный консультант по фруктам, селекиионер, Рим, Италия Эбрахим Латифихах
Научно-исследовательский центр сельского хозяйства и природных ресурсов, станиия Кашан, Кашан, И.Р. Иран

\section{Мирза Мусаев}

Институт генетических ресурсов НАНА, проспект Азадльг 155, AZ1106, Баку, Азербайджснн

\section{Бианкаелена Мазерти}

CNR-IPSP - Отдел биологических и пищевых наук, Институт по устойчивой защчите растений, Флоренция, via Madonna del Piano 10 , Флоренция, Италия

В настоящее время культивирование граната (Punica granatum) увеличилось в странах Средиземноморья из-за его питательных качеств и способности противостоять засолению почвы. Таким образом, знание механизмов его реакции на стресс окружающей среды приобретает все большее значение. С другой стороны, местные сорта, обычно выращиваемые в суровых условиях, могут представлять собой источник генов устойчивости, полезных для выведения новых устойчивых сортов. В данной работе пятимесячные почки 11 азербайджанских, шести иранских староместных сортов граната, а также почки сорта «Wonderful» были подвергнуты 48-часовому легкому холодовому стрессу $\left(-4^{\circ} \mathrm{C}\right)$. Параметры окислительного стресса, такие как перекисное окисление липидов, перекись водорода и пролин, а также активность супероксиддисмутазы измеряли в контрольных и стрессовых почках. При холодовом стрессе перекисное окисление липидов, уровень перекиси водорода и пролина были выше у всех сортов, чем у нормальных почек. Однако уровни изученных биомаркеров были ниже у иранского сорта «Савех» и азербайджанского «Бала Мурсал» по сравнению с современным сортом «Wonderful». Более высокий уровень ферментативной активности супероксиддисмутазы был обнаружен во всех почках, подвергнутых холодовому стрессу, особенно у почек сорта «Wonderful» по сравнению с нормальными. Эти результаты могут свидетельствовать о том, что староместные сорта «Савех» и «Бала Мурсал» в меньшей степени пострадали от холодового стресса. С другой стороны, сильная активация антиоксидантного фермента в «Wonderful» может иметь решающее значение для его выживания в условиях стресса. В этой работе показаны различия в параметрах окислительного стресса, а также в активности супероксиддисмутазы среди сортов граната при холодовом стрессе.

Ключевые слова: абиотический стресс, антиоксидантный фермент, староместные сорта, стресс растений, Punica granatum 